\title{
O TEATRO DE PESQUISA OU A PESQUISA NO TEATRO: O PROJETO GÊNERO E IDENTIDADE
}

Antônia Pereira

\begin{abstract}
Resumo
O objeto deste ensaio é o trabalho prático e teórico envolvendo professores e alunos da graduação e da pós-graduação em Artes Cênicas, da Escola de Teatro da Universidade Federal da Bahia, visando à construção de uma encenação/instalação/performance ancorada nas questões de gênero e identidade, tendo como material de base uma dramaturgia da memória dramaturgia construída a partir de histórias de vida dos atores sociais e teatrais implicados no processo dramatúrgico e cênico.
\end{abstract}

\section{Palavras-chave:}

Dramaturgismo; Identidade; Gênero.

\section{POR ONDE COMEÇAR?}

Foi-me solicitada, para o presente número da Revista Arteriais, uma reflexão acerca do Teatro de Pesquisa que venho realizando com meus alunos de graduação e pós-graduação já há alguns anos. A reflexão/exemplo mais à mão que tenho é, obviamente, meu atual projeto de Produtividade em Pesquisa, intitulado: "Dramaturgia, Dramaturgismo e memória: Histórias de vida como modelos de ação". Neste projeto, trabalho o teatro numa perspectiva teórica e prática, envolvendo professores e alunos da graduação e da Pósgraduação em Artes Cênicas, artistas profissionais e pesquisadores das Artes Visuais, da Música e da Performance. Problematizando as noções de gênero, identidade e poder a partir de histórias de vida, o ensejo primeiro desta investigação, consiste em instaurar uma prática de criação colaborativa em suas dimensões dramatúrgica e cênica, ancorando-se em memórias individuais e na metáfora do trabalho de Penélope ${ }^{1}$, proposta por Walter Benjamin. A memória dos atores envolvidos

\section{Abstract}

The object of this essay is the practical and theoretical work involving teachers and students of the undergraduate and postgraduate degree in Performing Arts, from the Theatre School of the Federal University of Bahia, which aims at building a staging / installation / performance anchored on the issues related to gender and identity. It has a drama of memory as the base material drama constructed after life stories of social and theatrical actors involved in the dramaturgical and scenic process.

\section{Palabras Clave:}

Drama; Identity; Gender.

neste processo constitui o ponto de partida para análise da questão da rememoração, cujo trabalho se encontra sempre entre a lembrança e o esquecimento, deixando-nos com a reminiscência:

\footnotetext{
Pois um acontecimento vivido é finito, ou pelo menos encerrado na esfera do vivido, ao passo que o acontecimento lembrado é sem limites, porque é apenas uma chave para tudo que veio antes e depois. Num outro sentido, é a reminiscência que prescreve, com rigor, o modo de textura (BENJAMIM, 1994, p. 37).
}

A narrativa e a figura do narrador, elementos que me são caros e que constituíram objetos de outro projeto de pesquisa sobre alteridade, memória e narrativa, no triênio 2007/2009, ressurgem aqui com força e vigor, não mais na perspectiva de criação em torno das minhas memórias, mas a serviço da memória do "outro" e num processo colaborativo que parte do estímulo à imaginação, para se chegar ao texto e à cena. A partir da história de vida dos atores, busca-se a construção de uma cena em que o testemunho da experiência de vida, através, portanto, da vivência, 
da imaginação e da rememoração dos fatos, constitui o coração da empreitada e guia todo o processo teórico e prático. A inserção/aparição da figura do narrador se dá numa perspectiva similar a de um confronto com a leitura de um livro: a trama a ser desenvolvida será a de um "livro vivo da personagem/ator/pessoa", narrador da história de vida, ressignificada em estrato de ficção. Nesse trajeto, somos confrontados às reminiscências das memórias, reminiscências erigidas em "inquietas sombras" do vivenciado, como uma espécie de flashback. Para solidificar tal trabalho sobre a memória do outro como pilar da criação dramatúrgica e cênica, não poderia me furtar à abordagem da dimensão política e social, abordagem esta que tem caracterizado minha trajetória como pesquisadora e conferido postura à minha produção intelectual desde a conclusão do doutorado em 1999 - os ensaios e artigos sobre Boal, Brecht e Armand Gatti, são alguns exemplos.

As noções de gênero, identidade e poder nortearão o trabalho com as reminiscências das memórias e trarão necessariamente à tona a noção de opressão. 0 trabalho com essas opressões rememoradas será feito na perspectiva de outra importante metáfora utilizada por Benjamin, para descrever a memória: o que fica são determinadas sínteses do muito vivenciado:

[...] Estas teimam em aparecer, por vezes em flashes, numa espécie de incômoda estranheza familiar". [...] A História não pode se basear na linearidade do tempo, mas sim no trabalho da memória, o qual percebe afinidades e semelhanças, encontra as marcas do tempo no espaço: "A historiografia (...) deixa de ser a narração de uma história de sucessos (e do sucesso) e explode em fragmentos e estilhaços - vale dizer: em ruínas" (SELIGMANN-SILVA, 2001, p.258).

Toda a dimensão prática do projeto teve início em março de 2015. Tanto em sua dimensão prática quanto teórica, o projeto conta, para além de bolsistas de Iniciação Científica, com a participação dos alunos de Licenciatura em Artes Cênicas, Bacharelado em Interpretação e Direção Teatral da Escola de Teatro, bem como de professores e alunos do Mestrado e Doutorado em Artes Cênicas da UFBA. Esse contexto implica a realização de pesquisa bibliográfica e produção de seminários e minicursos sobre as noções de dramaturgia, dramaturgismo, narração, epicidade e história de vida. A criação coletiva de textos sobre as noções de gênero, identidade e poder, a partir de processos criativos que partem das reminiscências da memória dos atores, constitui outra prerrogativa do projeto. Paralelamente, são promovidos debates, reflexões, acerca dos problemas encontrados nos textos escritos/situações/improvisações e suas futuras seleções e enquadramentos. Encontros com músico, artistas visuais e performers, de preferência discentes ou docentes pesquisadores vinculados a Programas de Pós-Graduação em Artes, estão previstos. Como para os projetos de Produtividade em Pesquisa anteriores, o resultado prático desta investigação foi e será submetido a editais nacionais e regionais de fomento à cultura, a exemplo da Chesf/Eletrobrás, Petrobrás, Funarte e FUNCEB, dentre os mais importantes. No momento fomos contemplados com o Edital Universal - MCT/CNPQ. Tendo pautado minha conduta até então, tal perspectiva não é inédita, mas o elemento inovador aqui e agora consiste na natureza colaborativa do processo de criação dramatúrgica e cênica.

\section{QUANDO TUDO COMEÇOU:}

Em 2010 o resultado prático do projeto de produtividade em pesquisa, intitulado: Do Texto à Encenação: Construções dramáticas e explorações cênicas em torno das noções de memória, alteridade e narrativa foi contemplado com edital Chesf de Teatro. Graças a este prêmio, em 2011, sob a insígnia Projeto Trilogia Memórias - minha Companhia Estupor de Teatro e diversos profissionais da música, das artes visuais e das artes cênicas realizaram uma turnê por 6 capitais brasileiras: Salvador, Aracaju, Recife e Fortaleza no Nordeste; Porto Alegre e Curitiba no Sul. Durante a turnê em cada capital, de quinta-feira a sábado, eram sucessivamente apresentados três textos da minha autoria, A Morte nos Olhos, $A$ Memória Ferida e Na Outra Margem, encenados e interpretados por meus orientandos, num grande projeto teórico prático sob minha coordenação.

Os mesmos ensejos me impulsionam nesse momento em que, ao termo de três anos na coordenação da área de Artes/Música, na CAPES, em vez de três espetáculos, vislumbro um grande espetáculo/performance/instalação de 3 a 4 horas, envolvendo as três grandes áreas de Artes (artes visuais, música e artes cênicas), na execução de uma performance ao vivo, que interrogue e 
problematize três grandes temas tão em pauta na contemporaneidade: questões de gênero, identidade e poder! Outro grande desejo singular diz respeito à preferência por pesquisadores docentes ou discentes de Programas de PósGraduação em Artes, para composições musicais, visuais e cenográficas deste espetáculo/ performance/instalação que ao termo de sua realização, constituir-se-á numa grande enquete política/artística/sociológica.

Minhacuriosidadepelotema, paraalém dasquestões de ordem pessoal e política, é fundamentalmente determinada pela complexidade dos conceitos aqui em pauta e suas relações com a produção escrita e a criação cênica. Nesse sentido, outra problemática aqui suscitada, diz respeito às tensões que vão do processo colaborativo de criação dramatúrgica até sua concretude (e/ou completude?): a encenação. É nessa perspectiva que a presente investigação conclama, em sua práxis metodológica, as noções de dramaturgia, dramaturgismo, narratividade, epicidade, interrupção e "experiência do choque". Este caminho para visa a validação das hipóteses levantadas tanto no processo da produção/ construção colaborativa do texto/situação dramátic(a)o, quanto da produção/construção do espetáculo final. Neste estado da questão, o recurso às literaturas voltadas para estas problemáticas se faz com fins eminentemente pragmáticos, ou seja: apenas quando um problema de ordem textual dificulta sua materialização (solução) cênica.

Necessário se faz assinalar que este projeto se inscreve no âmbito das disciplinas da graduação Dramaturgia le l/e Semiologia do Teatro-e da PósGraduação - Formas do Espetáculo. 0 objetivo aqui consiste na - através de uma perspectiva integrada e interdisciplinar - promoção de intercâmbios e trocas entre as diferentes dimensões/fases teóricas e práticas da investigação. Essa forma de diálogo entre disciplinas teóricas e disciplinas práticas - a experiência profícua resultante caracterizou, com efeito, nossos projetos anteriores de produtividade em pesquisa, garantindo-Ihes eficácia e êxito.

\section{DELIMITAÇÃO DO OBJETO: A PROBLEMÁTICA}

A finalidade prática deste estudo consiste na montagem de um espetáculo/instalação/ performance acerca das questões de gênero, identidade e poder, tendo como material de construção uma dramaturgia da memória, construída a partir de histórias pessoais dos atores envolvidos no processo dramatúrgico e cênico, na perspectiva colaborativa. Em cada uma das partes desse grande espetáculo, a narrativa, a história de vida, conceito que me é caro e familiar, constituirá o "fio de Ariadne" ao longo de todo o trajeto. Seguindo essa pista assumo naturalmente o ponto de vista da dramaturgista, da agenciadora e organizadora de materiais textuais oriundos de uma dramaturgia colaborativa, entendida aqui na acepção de Jacó Guinsburg:

[...] um tipo de criação em que o texto dramático não existe a priori, vai sendo construído juntamente com a cena, requerendo com isso a presença de um dramaturgo responsável, numa periodicidade a ser definida pela equipe. Nesse espírito, todo material criativo (ideias, imagens, sensações, conceitos) deve ter expressão na forma de cena - escrita ou improvisada/representada. Como consequência, a cena como unidade concreta do espetáculo ganhará importância fundamental no processo colaborativo (GUINSBURG, 2001, p. 86).

A singularidade desta investigação, como já foi dito, reside na exploração de uma dramaturgia da memória, fruto das reminiscências, das vivências dos atores implicados na pesquisa teórica e prática. Uma vez mais exploramos, em primeiro plano, o conceito de narrativa ${ }^{2}$ e a técnica da história de vida! Uma vez mais recorremos ao princípio ${ }^{3}$, conhecido por diversas teorias, o de que a finalidade de uma narrativa é sempre a de unir, a de integrar em todos os sentidos da palavra. Nessa perspectiva, o espetáculo/performance/instalação sobre as questões de gênero, identidade e poder evidencia as contribuições da narrativa em três sentidos:

1. Psicológico (integração psicológica): quando a narrativa consiste em produzir uma continuidade no curso de uma vida, reduzindo as fraturas e os traumatismos;

2. Sociológico (integração sociológica): quando a narrativa consiste num rito de passagem para introduzir-se numa comunidade. De fato, integrarse numa coletividade começa muitas vezes por uma autobiografia, mais ou menos formal, na qual se manifesta um tipo de dom que vai de si ao outro, do individual ao coletivo.

3. Filosófico, finalmente (integração filosófica): quando a narrativa consiste em reconhecer, no curso de uma vida, a presença de um Princípio ou do Ser.

Partindo destas contribuições, discuto as diversas 
formas da narrativa, da história de vida e sua eficácia simbólica, porque se trata, com efeito, do meio mais frequente e funcional de encontrar, compreender o outro e se aproximar de sua experiência, tanto na vida cotidiana, quanto numa pesquisa de criação cênica.

\section{SISTEMA CONCEITUAL}

Esta primeira etapa do sistema conceitual diz respeito ao Quê da investigação: os temas que são problematizados no espetáculo/performance/ instalação e que constituem a matéria-prima da criação dramatúrgica e cênica, numa perspectiva colaborativa. Desse modo, os conceitos e noções, a seguir arrolados, são dissecados e analisados à luz da filosofia, da semiologia, da literatura teatral, da teoria do drama e da sociologia, dentre os domínios mais importantes.

Gênero: não se pode tentar definir a noção de gênero sem efetuar uma breve incursão na teoria psicossociológica das "representações sociais", buscando estabelecer algumas pontes com as teorias "feministas de gênero". O conceito de gênero exige um sobrevoo sobre as teorias de Moscovici - suas variações e pontos de convergência com as teorias feministas. Embora oriundo da sociologia de Durkheim, é na psicologia social que a representação social ganha uma teorização - desenvolvida por Serge Moscovici - com aprofundamento efetuado por Denise Jodelet. A partir dos anos 60, com a intensificação do interesse pelos fenômenos da ordem do simbólico, vemos florescer a preocupação com explicações para as questões de gênero e de representações sociais, as quais recorrem às noções de consciência e de imaginário. Também a obra Problemas de gênero: feminismo e subversão da identidade (2010), da filósofa pós-estruturalista estadunidense, Judith Butler, será de grande aporte ao aprofundamento desta reflexão. Sem negligenciar a importância das construções sociais e culturais na constituição do mundo e dos sujeitos tal como os conhecemos, a teoria de Butler demonstra que não são bemsucedidas todas as tentativas de ilustrar o caráter social de estruturas que parecem tão naturalizadas: o corpo, o sexo, as diferenças. Refletindo a partir das oposições binárias, a filósofa traz a dimensão biológica para o campo do social, aportando contribuições significativas aos estudos de gênero. O interesse particular pela filosofia de Butler reside na tese segundo a qual a repetição de atos, gestos e signos do âmbito cultural, reforçariam a construção dos corpos masculinos e femininos e a conclusão de que se trata, essencialmente, de uma questão de performatividade. Gênero, para Judith Butler, é um ato intencional, um gesto performativo que produz significados.

Identidade: semioticamente, identidade constitui um conceito indefinível que se opõe a outro do mesmo gênero: alteridade. Na melhor das hipóteses, este par pode ser considerado como interdefinível, por natureza, em função da relação de pressuposição recíproca. Assim como a identificação permite muitas conjeturas em torno da identidade de dois ou mais objetos, do mesmo modo a distinção torna-se a operação através da qual se reconhece suas alteridades. Neste domínio, as teorias de Stuart Hall acentuam a questão da identidade a partir do argumento segundo o qual "as velhas identidades, que por tanto tempo estabilizaram o mundo social, estão em declínio, fazendo surgir novas identidades e fragmentando o indivíduo moderno, até aqui visto como um sujeito unificado" (HALL, 2006, p. 60). Desse ponto de vista, a "crise de identidade" é vista como parte de um processo mais amplo de mudança, que está deslocando as estruturas e processos centrais das sociedades modernas e abalando os quadros de referência que davam aos indivíduos uma ancoragem estável no mundo social.

Poder: conceito indissociável da teoria das organizações e que no campo dessa investigação evoca uma reflexão e discussão sobre as implicações que o termo adquire na teoria organizacional da concepção de poder do filósofo Michel Foucault, a qual serve de base para o que ele denominou de poder disciplinar. o pressuposto segundo o qual nas relações de produção também há produção de sujeitos, nos leva ao argumento de que um tipo de sujeito é almejado pelo sistema capitalista, de modo a manter seu ciclo de acumulação. As análises propostas por Foucault indicam que o que está em questão nas relações de poder capitalistas é a produção de um sujeito que tenha sua capacidade produtiva econômica liberada e a política inibida. Para Michel Foucault, além da produção de bens, existe a produção de sujeitos, um tipo de sujeito para o capitalismo liderado pelos meios de comunicação de massa, pelas instituições religiosas e educacionais, assim o sujeito tornase dócil politicamente e útil economicamente. 0 
que interessa para Foucault não é a construção de um novo conceito, mas a análise do poder na prática social, uma teoria só Ihe é útil se ela Ihe possibilitar condições para atingir seus objetivos. A partir da discussão que coloca o poder somente no nível econômico e das alternativas que associam o conceito à repressão ou à guerra, Foucault começou a delinear uma nova forma de pensar o poder. Por um lado o poder seria a propriedade de uma classe que o teria conquistado, por outro o estado teria o poder.

O interessante desta análise é, justamente, concluir que os poderes não estão localizados em nenhum ponto específico da estrutura social, ele é um conjunto das relações de força, que passam pelos dominantes e dominados. Ainda segundo Foucault, existem três afirmações para concepção do poder: na primeira o poder não é essencialmente repressivo; na segunda, exerce antes de se possuir; e na terceira, não menos importante, passa tanto pelos dominados quanto pelos dominantes.

Habitus: para além de Foucault, a noção de poder suscita, ainda, um exame do conceito de Habitus de Pierre Boudieu, entendido aqui como um conceito capaz de conciliar a oposição aparente entre realidade exterior e as realidades individuais. Capaz de expressar o diálogo, a troca constante e recíproca entre o mundo objetivo e o mundo subjetivo das individualidades. Habitus é então concebido como um sistema de esquemas individuais, socialmente constituído de disposições estruturadas (no social) e estruturantes (nas mentes), adquirido nas e pelas experiências práticas, em condições sociais específicas de existência - constantemente orientado para funções e ações do agir cotidiano: $O$ habitus é uma subjetividade socializada (BOURDIEU, 1996, p. 101).

Memória: Benjamin nos lembra em O Narrador que a memória é a mais antiga das faculdades épicas. A noção de memória diz respeito tanto às estruturas físicas quanto psíquicas. Não existe uma, mas várias memórias. A exemplo de Paul Ricoeur, nos interessaremos aqui pela memória a longo prazo: aquela que estoca informações durante um longo período ou mesmo, durante toda uma vida. Dotada de uma considerável capacidade, a memória a longo prazo é depositária das nossas lembranças, das nossas aprendizagens, em suma, da nossa história. Além da filosofia e da fenomenologia, a literatura científica e psiquiátrica, por sua vez, poderá nos fornecer muitas pistas na compreensão desta estranha função que nos permite captar, codificar conservar e restituir os estímulos e informações que recebemos. A memória sempre consistiu em terreno profícuo para estudos e experiências nas artes cênicas. Na busca por uma arte menos mecânica, mais orgânica; por um corpo-vida, muitos encenadores se valeram de técnicas de acesso aos recursos e conteúdos potenciais e virtuais da memória. Em alusão ao Erkennbarkeit de Benjamin, Olgária Matos afirma que "o aprender é o recordar - mas como apreensão de um presente que se constrói com os fios e motivos de um bordado, como no sentido etimológico de Kairós (MATOS, 1992, p. 240), como uma constelação dialética, onde nenhuma estrela isoladamente tem sentido". $\mathrm{Na}$ ideia de tempo Kairós, não é necessário organizar mentalmente a linha sucessiva das recordações. Elas estão estampadas no Corpo-memória.

Narrativa - (récit): termo da linguagem corrente, empregado quase sempre para designar discursos narrativos de caracteres (ou seja, discursos comportando personagens que executam ações). Por tratar-se de um esquema narrativo acionado no discurso e, por essa razão, inscrito em coordenadas espaços-temporais, muitos semioticistas, após V. Propp, definem a narrativa como uma sucessão temporal de funções (no sentido de ações). Contar uma história pressupõe outro (alteridade), ainda que este outro não seja mais do que um desdobramento de si mesmo (identidade). Para Contar é necessário distanciamento, vivência passada, ainda que remota; pressupondo um apelo inexorável à memória: e o limite do inteligível é o memorável. O que não se pode lembrar não se pode narrar!

\section{DEPOIS DO QUÊ, O COMO?}

Na via da criação dramatúrgica e cênica, num segundo momento, outros conceitos são arrolados e aplicados à prática desta pesquisa, quais sejam:

Epicidade:para Staiger oépico como traço estilístico "[...] apresenta, aponta alguma coisa, mostra-a" (STAIGER, 1975. p.108). O acontecimento épico caracteriza-se por sua distância, por sua oposição ao presente, por ser passado, pela atividade de rememoração. A epicizaçãodas narrativas pessoais é tratada no contexto desta investigação em 
estreita associação ao tratamento benjamininano dos conceitos de crítica, experiência e choque.

Experiência e Choque: no projeto de produtividade em Pesquisa 2007/2009 trabalhei com a narrativa e a memória, partindo dos conceitos de petrificação e estupor - estado de suspensão da consciência quando de situações onde a compreensão da realidade pela consciência se interrompe. Já na antiguidade, os gregos tinham consciência de tal possibilidade e representavam-na nas figuras das Górgonas. Tendo em vista o aspecto colaborativo e a dimensão política deste trabalho, ancorado em uma dramaturgia da memória, mais adequados e legítimos do que os conceitos de estupor e petrificação, nos parecem o conceito de interrupção (Unterbrechnung). Associado imediatamente à função do gesto, Unterbrechnung constitui um conceito central, segundo Benjamin, para o entendimento do gênero épico. O filósofo relaciona o conceito de interrupção ao da vivência do choque (Schockerlebnis), assimilando-o às noções de montagem cinematográfica e do estranhamento como efeito [no teatro] e como meios técnicoartísticos de invenção de uma nova narratividade.

Experiência e Vivência: a noção de experiência individual ou vivência (Erlebnis), ainda para Benjamin, substituiu, na sociedade moderna, a experiência coletiva e compartilhada (Erfahrung). A vivência do choque (Schockerlebnis) é uma espécie de choque perceptivo, fruto da tecnicização, do automatismo, da velocidade da vida moderna. A arte, para expressar e discutir essa nova percepção cria princípios de trabalho como a collage, a montagem, a interrupção da ação.

Ao termo da exposição dos conceitos essenciais, toco no ponto preciso em que a metodologia da pesquisa, nas vias da criação teatral, naturalmente se impõe!

\section{DA METODOLOGIA: OS ITINERÁRIOS DA PESQUISA}

De posse desses conceitos e construída a argumentação de base, os mitos, as fábulas resultantes, textuais e cênicas, desta pesquisa funcionam com modelo na perspectiva ampliada de protótipo, como algo em construção; estruturado, mas aberto. Uma fábula aberta ao experimento e construída a partir de experiências e vivências pessoais do "choque". Para garantir a dimensão política e não sucumbir ao risco de psicologizar o processo colaborativo, recorro às teses sobre a noção de história de Walter Benjamin; trato o rastro, a lembrança e os esboços como possibilidade de estabelecer analogias entre o passado e o presente, depreendendo esforços para indicar uma construção histórica que encontra a presença do passado no presente e um presente já prefigurado no passado.

Tal acepção de história está atrelada às citadas noções da filosofia benjaminiana de Ehrfarung (experiência) e Erlebnis (vivência). Na busca por uma dramaturgia da memória, a construção de uma fábula a partir da experiência, recupera elementos da linguagem narrativa na estrutura épica e na sua proposta pedagógica de jogo entre atuantes, justamente porque é operada, a partir das estratégias de identificação e de distanciamento. Nessa empreitada o narrador ocupa a dianteira da cena - um narrador capaz de articular vivência e experiência de forma criativa. A pesquisa prática, o processo e o produto artístico final, são norteados pelos conceitos fundamentais da poética de Emil Staiger (1975). E no lugar da noção de drama absoluto de Peter Szondi (2001), para a construção colaborativa tanto do texto, quanto da cena, adotase a perspectiva da dramaturgia aberta, formulada por Gerd Bornheim, em oposição à noção de dramaturgia fechada ou aristotélica.

O conceito de epicização e o constante apelo ao gênero épico, não devem significar aqui, um abandono de outras formas narrativas, outros gêneros. À maneira de Staiger (1975), que refuta uma poética ahistórica, sublinhamos no "caminho para", a necessidade de construir uma formulação do lírico, do épico e do dramático como construções históricas, rejeitando um programa a priorístico. Lembremos que nesse sentido Staiger efetuou uma substituição do Lírico, do Épico e do Drama como formas substantivas e substancialistas, designando os conceitos estilísticos de lírico, épico e dramático enquanto instâncias adjetivas, o que os confere temporalidade e função. O grande interesse com isso é de que o espetáculo/performance/instalação resultante, assim como seus agenciadores, sejam multirreferenciais em termos de linguagens estilos e formas (convenções). 


\section{NA VIA DO PROCESSO COLABORATIVO: DRAMATURGIA OU DRAMATURGISMO?}

No lugar preciso onde o Quê e o Como se fundem em nosso horizonte metodológico, necessário se faz sobrevoar as noções de dramaturgia e dramaturgismo, apontando em que medida um ou outro conceito, ou os dois ao mesmo tempo, são empregados na dimensão prática - da cena ao texto ou do texto à cena - desta investigação. A discussão de qualquer dos dois conceitos pressupõe antes uma definição de mito ou fábula. Em seu Dicionário de Teatro, Pavis apresenta o verbete fábula através de sua construção histórica, classificando inicialmente duas concepções opostas, a de fábula como material anterior à composição da peça e a de fábula como estrutura narrativa da história.

Nessa perspectiva, historicamente se pode distinguir três possibilidades de definição/ delimitação da fábula:

\section{Fábula como matéria;}

\section{Fábula como estrutura da narrativa;}

\section{Fábula como ponto de vista sobre a história.}

Para Pavis, fábula é a versão latina do termo grego mythos. 0 mythos é a matéria fundante, anterior propriamente ao assunto, construído este, por sua vez, no manejo do dramaturgo da matéria original. É o "conjunto de motivos que se pode reconstituir num sistema lógico ou dos acontecimentos ao qual o dramaturgo recorre". Os mitos explorados no âmbito desta enquete são extraídos da Ehrfarung (experiência) e Erlebnis (vivência) dos atores; são explorados na perspectiva da montagem e interrupção (Unterbrechnung), em consonância com o imaginário e o potencial criativo dos sujeitos envolvidos (suas reminiscências, fragmentos de memória, rastros, lembranças); são fundamentados na técnica do collage, enfatizando a epicidade sem deixar de recorrer, quando necessário à lírica e à dramática com o objetivo de conferir à enquete uma dimensão cênica tão importante e impactante quanto a dimensão teórica.

A construção da fábula implica, ainda, numa tomada de posição sobre a história e a História. A tomada de posição prevê um trabalho de leitura, de interpretação. Este trabalho do fabulador, compartilhado entre os atores e dramaturgista, visa instaurar um processo dialético que não se esgota e que revela um trabalho permanente de investigação e exposição de um ponto de vista sobre a realidade. A fábula é, portanto, fruto do trabalho do fabulador. E permanece em perpétua elaboração não só no nível da redação do texto dramático, mas também e, sobretudo, no processo de encenação e de interpretação.

Sempre segundo Pavis, a dramaturgia, no seu sentido mais recente tende, portanto, a ultrapassar o âmbito de um estudo do texto dramático, para englobar o texto e a realização cênica (PAVIS, 2005, p.114). No caso francês, o dramaturgo normalmente é um profissional que atua como um "conselheiro literário e teatral agregado a uma companhia, a um encenador ou responsável pela preparação de um espetáculo" (PAVIS, 2005, p. 117). Nessa perspectiva, dentre as atribuições do "dramaturgo", didaticamente Pavis enumera algumas que permeiam a prática da dramaturgia no Brasil:

Combinar os textos escolhidos para uma mesma encenação; [...] efetuar as pesquisas de documentação sobre e em torno da obra; [...] adaptar ou modificar o texto; [...] destacar as articulações de sentido e inserir a interpretação num projeto global (social, político, etc.); [...] intervir de tempos em tempos, durante os ensaios, como um observador crítico cujo olhar é mais "fresco" do que aquele do encenador [...] o dramaturgo é então o primeiro crítico interno do espetáculo em elaboração (PAVIS, 2005, p. 117).

A distinção entre dramaturgia e dramaturgismo teve lugar pelo fato de que em alemão essas duas figuras se distinguem pelos termos dramaturg (dramaturgo) e dramatiker (autor dramático). 0 sentido da palavra dramaturg no Brasil passou a significar "autor dramático" e, mais recentemente, originou o neologismo dramaturgista, que significa a atividade do dramaturg. 0 escritor de peças aqui poderá ser chamado de dramaturgo ou de autor de teatro, mas se exercer apenas as funções de dramaturgindicadas por Pavis e não escrever peças de punho será chamado de dramaturgista. Para Pavis, ao montar uma peça, o encenador também cumpre em parte a função de dramaturgo, pois é responsável pela leitura e adaptação da cena:

A partir do momento em que há encenação, podese considerar que há necessariamente um trabalho dramatúrgico, mesmo - e, sobretudo - que este seja negado pelo encenador em nome de uma fidelidade à tradição, ou de uma vontade de tomar o texto "ao pé da letra" etc. Com efeito, toda leitura e, a fortiori, 
toda representação de um texto pressupõem uma concepção das condições de enunciação, da situação e da interpretação dos atores etc. Esta concepção, ainda que embrionária ou sem imaginação, já é em si uma análise dramatúrgica que compromete uma leitura do texto (Ibid, p. 117).

Em sua obra 0 discurso da cumplicidade: dramaturgias contemporâneas, Ana Pais aponta certa invisibilidade no ofício dramatúrgico, por se tratar de uma prática com procedimentos que tendem a se dissolver no processo de criação, permanecendo ali presente de forma latente, mas não mais material, característica que a autora denomina de aspecto performativo orgânico. Já no século XVIII, Lessing problematizou o termo Dramaturg, enquanto preparava o campo para o novo trabalho do dramaturgista: o de estabelecer a consciência crítica, no contexto da fundação de um teatro nacional. Desenhavam-se ali duas novas possibilidades para a dramaturgia:

1. relativa à atividade do dramaturgista no processo de criação de um espetáculo: composição dramática, desempenhando tarefas relativas à produção teatral;

2. relativa à dramaturgia institucional (responsável pelo repertório do teatro, pelo espaço físico, por sua promoção).

Ainda para Ana Pais é com Brecht, que de fato o dramaturgista se torna uma função autônoma na equipe criativa e seu papel consiste em selecionar e enquadrar. É exatamente neste sentido que, no meu atual projeto de pesquisa, desempenho a função de dramaturgista, encarregando-me de montar o espetáculo/performance/instalação, assumindo a responsabilidade estética e organizacional de todo o ritual, escolhendo os atores, interpretando os textos/situações produzidos/improvisados, utilizando as possibilidades cênicas à disposição, selecionando-as e enquadrando-as. Essa pesquisa situa-se justamente no terreno onde a dramaturgia e a encenação teatral abraçam a experiência e a vivência do choque, as histórias de vida. Aqui a tríade dramaturgia/história de vida/encenação é mais uma vez acessada para abrir as portas do drama aos eventos relacionados ou ocasionados pela memória e a alteridade. Eventos estes reconstituídos e fixados sob a forma de narrativa dramática. Se até o momento, me limitei a elencar conceitualmente os grandes temas desta enquete (gênero, identidade e poder), e a projetar futuras e mais densas problematizações, é porque é na via do dramaturgismo, da exploração de histórias de vida que adensare(i)mos e conferire(i)mos dramaticidade e espetacularidade a tais noções.

Minha trajetória de teórica e artesã das artes do espetáculo provou que as convenções e gêneros da encenação e da interpretação dos atores são desenhados no e pelo processo/percurso, em função da equipe (atores, músicos, cenógrafos, figurinistas lightdesigner), seus imaginários, suas exigências estéticas, éticas etc. Posso esboçar, desde já e, entretanto, que para o trabalho com histórias de vida e técnicas de interpretação teatral, a psicotécnica de Stanislavski, precisamente o como "se" de que se vale o ator para a criação de uma situação fictícia inspirada na experiência real, está sendo de grande aporte. Os meios para se alcançar a organicidade no processo artístico, dentre os quais as técnicas de sugestionamento, ao lado dos cânticos sagrados, dos quais se valem Grotowski, também podem conferir densidade ao grande espetáculo/perfomance/instalação resultante. 0 treinamento dos atores, precisamente o trabalho de corpo, está sob minha responsabilidade e é todo ele inspirado no Qi Gong ou Chi Kung, ginástica terapêutica e preventiva chinesa, da linha Lian Gong/Qi Gong, que pratico e a qual me dedico desde o início de 2004. Qi Gong ou Chi Kung que significa literalmente "exercícios de energia" é uma terapêutica que consiste em práticas milenares usadas para estimular, nutrir e canalizar o fluxo de energia na rede de meridianos do organismo humano, revitalizando o corpo e a mente. Constitui um dos pilares da Medicina Chinesa, juntamente com a Fitoterapia/Farmacologia, Dietoterapia, Tui Ná e Acupuntura/Moxabustão.

Sobre o projeto Gênero e Identidade em seu atual estado, a pesquisa teórica e prática exige o exame e comparação minuciosa dos métodos e teorias acerca das noções de Gênero e Identidade, tendo como material de base uma dramaturgia da memória - dramaturgia construída a partir de histórias de vida dos atores envolvidos no processo colaborativo, dramatúrgico e cênico. A especificidade da presente investigação consiste em interrogar, a exemplo de Judith Butler, se há de fato um gênero que as pessoas possuem, conforme se diz, ou é o gênero um atributo essencial do que se diz que a pessoa é, como implica a pergunta "qual é o seu gênero"? 
Nessa perspectiva, na prática, quer dizer em sua performance/atuação cênica, o ator deve se debruçar sobre as performances/discursos cisgêneros, transsexuais (trans boy, trans lésbica, etc.). As resultantes cênicas devem partir do princípio defendido por Butler, segundo o qual

Quando o status construído do gênero é teorizado como radicalmente independente do sexo, o próprio gênero se torna um artifício flutuante, com a consequência de que homem e masculino podem, com igual facilidade, significar tanto um corpo feminino como um masculino, e mulher e feminino, tanto um corpo masculino como um feminino (BUTLER, 2003, p. 28).

Nesse mesmo espírito, Butler ressalta, ainda:

[...] Embora os cientistas sociais se refiram ao gênero como um 'fator' ou 'dimensão' da análise, ele também é aplicado a pessoas reais como uma 'marca' de diferença biológica, linguística ou cultural. "Nestes últimos casos, o gênero pode ser compreendido como um significado assumido por um corpo (já) diferenciado sexualmente; contudo, mesmo assim esse significado só existe em relação a outro significado oposto (IBID, p. 28).

Outra importante abordagem, consiste na problematização de tais questões na perspectiva dos debates feministas contemporâneos, da crítica ao essencialismo que coloca de outra maneira a questão da universalidade da identidade feminina e da opressão masculina. Nessa direção, sobre gênero especificamente.

[...] as discordâncias tão agudas sobre o significado de gênero - se gênero é de fato o termo a ser discutido, ou se a construção discursiva do sexo é mais fundamental, ou talvez a noção de mulheres ou mulher e/ou de homens ou homem - estabelecem a necessidade de repensar radicalmente as categorias da identidade no contexto das relações de uma assimetria radical do gênero (Ibid, p. 30).

No tocante à identidade, recorre-se a Stuart Hall, o qual discute a emergência de uma suposta "[...] 'crise de identidade' na modernidade tardia, uma vez que as antigas e estáveis identidades estariam em declínio, o que culminaria na ascensão de novas identidades que apontam para a existência de um sujeito moderno fragmentado (HALL, 2006, p. 45). Stuart Hal propõe-se a explorar as questões acerca da identidade, a fim de avaliar se, realmente, existe uma crise de identidade, considerando o conceito de identidade complexo, mas alertando que isso não impede de formular discussões e suscitar a reflexão em torno da ideia de que as identidades estão sendo descentradas, ou seja, deslocadas, fragmentadas.
Perseguindo estas pistas, consequentemente suscito questões transversais de interesse de várias áreas do conhecimento, seja no reino das ciências humanas ou no reino das artes. A ênfase é colocada na encenação de narrativas pessoais, na produção e representação de histórias de vida que alimentem e motivem o debate acerca do que significa dramatizar questões de Gênero, interrogando a noção de identidade e reunindo as diversas linguagens das artes em níveis de graduação e pós-graduação. Como esses amplos e tão contemporâneos conceitos se colocam no universo particular de uma pesquisa dramatúrgica e cênica? Por que mesmo querer compreender o outro, sua história, seu gênero, sua identidade, numa perspectiva de criação colaborativa? Se não aportar respostas satisfatórias a estas questões, no mínimo a dimensão prática deste projeto suscitará novas perguntas.

Nesse contexto, a pesquisa teórica, o processo e o produto artístico final exploram uma dramaturgia da memória, fruto das reminiscências, das vivências do grupo de atores já selecionados para pesquisa prática, cujos encontros têm lugar todo final de semana, na Escola de Teatro da Universidade Federal da Bahia. A partir das histórias de vida, será montado em setembro/outubro de 2015 um espetáculo/ performance/instalação sobre as questões de gênero, primeira parte de uma trilogia sobre gênero, identidade e poder. Nesta perspectiva, as narrativas extraídas das reminiscências da memória dos atores são exploradas em consonância com o imaginário e o potencial criativo dos discente/artistas/ pesquisadores das Artes Cênicas - Teatro e Dança e da Música. Tal trajeto é efetuado em função das exigências estéticas do grupo envolvido e do objetivo primordial desta investigação: conferir à enquete dimensões eminentemente teóricas e cênicas.

Assim, os mitos, a fábulas resultantes, textuais e cênicas, desta pesquisa funcionam como modelo na perspectiva ampliada de protótipo, como algo em construção; estruturado, mas aberto. Uma fábula aberta ao experimento e construída a partir de narrativas, experiências e vivências pessoais do "choque".

\section{NOTAS}

1. Esposa de Ulisses, o qual partiu para a Guerra 
de Tróia, retornando dez anos depois. Em uma das versões do mito, Penélope fazia os pretendentes esperarem que terminasse de tecer uma mortalha para o corpo de Laertes, pai de seu marido, antes de assumir algum outro compromisso, porém a desfazia à noite num trabalho interminável.

2. Na teoria sociológica ou antropológica, por exemplo, a narrativa é também chamada "entrevista não diretiva de pesquisa" ou "história de vida": um pesquisador convida um ator social comum a produzir uma narrativa sobre um fato ou experiência vivida.

3. Dizemos uma vez mais por que tais princípios nortearam nossas pesquisas dramatúrgicas e cênicas no âmbito do Projeto $P Q$, intitulado Do Texto à Encenação: Construções dramáticas e explorações cênicas em torno das noções de memória, alteridade e narrativa, triênio 2007-2009.

\section{REFERÊNCIAS}

BENJAMIN, W. A imagem de Proust. In Magia e técnica, arte e política: ensaios sobre literatura e história da cultura. São Paulo: Brasiliense, 1994.

BOURDIEU, P. Poder Simbólico. Lisboa: Difel, 1989.

- Razões Práticas: sobre a teoria

da ação. Campinas: Papirus, 1996.

BUTLER, J. Problemas de Gênero. Feminismo e subversão da identidade. Rio de Janeiro: Civilização Brasileira, 2003.

FOUCAULT, Michel. Microfísica do poder. Rio de Janeiro: Edições Graal, 1981.

Vigiar e punir: história da

violência nas prisões. 10 ( Ed.

Petrópolis: Vozes, 1993.

GUINSBURG, J. Texto ou pretexto. In Sala Preta, Revista da ECA/USP, V 1, n) 1, 2001.

HALL, S. A identidade cultural na pósmodernidade. Trad. Tomaz Tadeu da Silva, Guarareira Lopes Louro. 11 ed. Rio de Janeiro: DP \& A Editora, 2006.

JODELET, D. Folie et représentations sociales.
Paris: PUF, 1989.

MATOS, O. A Rosa de Paracelso. In: Adauto Novaes. (Org.). Tempo e História. São Paulo: Companhia das Letras, 1992.

MOSCOVICl, S.; MARKOVA, I. Presenting social representations: a conversation. Culture \& Society, v. 4, n. 3, p.371-410, 1998.

MOSCOVICl, S.; NEMETH, C. Minority influence. In: NEMETH, C. (org.). Social psychology: classic and contemporary integrations. Chicago: Rand McNally, 1974.

PAIS, A. O discurso da cumplicidade: dramaturgias contemporâneas. Lisboa: Edições Colibri, 2004.

PAVIS, P. Dicionário do Teatro. São Paulo: Perspectiva, 2005.

STAIGER, E. Conceitos Fundamentais da Poética. Rio de Janeiro: Tempo Brasileiro, 1975. (Biblioteca Tempo Universitários)

SELIGMANN-SILVA, M. Ler o Livro do Mundo Walter Benjamin. São Paulo: Iluminuras. 2001, p. 256.

SZONDI, P. Teoria do Drama Moderno (18801950). São Paulo: Cosac \& Naify Edições Ltda., 2001.

\section{Sobre a autora}

Atriz e dramaturga, graduada em Licenciatura em Artes Cênicas, pela Universidade Federal da Bahia (1992); Mestre (DEA) em Litterature Française, pela Université de Toulouse II, Le Mirail (1994); Doutora em Lettres Modernes, pela Université de Toulouse II, Le Mirail (1999) e Pós-Doutora em Dramaturgia, pela Université du Québec à Montréal UQAM (2006). Coordenou o Programa de PósGraduação em Artes Cênicas (PPGAC/UFBA) por duas gestões consecutivas - biênios 2007/2009 e 2009/2011.Também foi segunda secretária eleita para o biênio 2000/2002 da Associação Brasileira de Pesquisa e Pós Graduação Em Artes Cênicas. Atualmente é professora Associada III da Universidade Federal da Bahia, integra os Grupos de Pesquisa DRAMATIS e GIPE-CIT e Coordena da Área de Artes/Música na CAPES. 